\title{
The Mediating Effect of Psychological Quality of Innovation and Entrepreneurship Education on Graduate Students' Innovation and Entrepreneurship Ability and Willingness
}

\author{
Zihan Wang ${ }^{1} \quad$ Yifan Zuo $^{1} \quad$ Sirong Chen $^{1} \quad \mathrm{Mu}$ Zhang ${ }^{1,2 *}$ \\ 1. Shenzhen Tourism College of Jinan University 6 Qiaocheng East Street, Nanshan District, Shenzhen city \\ 2. Shenzhen Tourism College, Jinan University, Shenzhen, Guangdong Province, China \\ * E-mail of the corresponding author:zhangmu@163.com
}

This work was supported by the Degree and Graduate Education Reform Key Projects of Guangdong Province, and the title is Exploration and Practice of Postgraduate Cultivation in Incorporating Innovation and Entrepreneurship Consciousness. Also, it was supported by the project of China Higher Education Association Thirteenth Five-Year Plan for Scientific Research in Higher Education (Grant number: 2018SYSZD08).

\section{Abstract}

Under the background of the innovation and entrepreneurship ability improvement plan proposed by the Ministry of education of China, the research on the subject of entrepreneurship and innovation is conducive to the continuous deepening of innovation and entrepreneurship education reform in Colleges and universities, and the continuous training and delivery of high-level talents for the construction of an innovative country. This paper explores the relationship among innovation and entrepreneurship ability, innovation and entrepreneurship education psychological quality and innovation and entrepreneurship willingness through a questionnaire survey of graduate students in Colleges and universities, analyzes the current situation, further confirms the hypothesis among the three, obtains positive results, and puts forward some countermeasures and suggestions for higher education.

Keywords: Higher education, Graduate students, Willingness of innovation and entrepreneurship, Innovation and entrepreneurship ability, Psychological quality of innovation and entrepreneurship education

DOI: $10.7176 / \mathrm{JEP} / 11-19-06$

Publication date:July $31^{\text {st }} 2020$

\section{Introduction}

Since the 1990s, colleges and universities in developed countries, especially in the United States, have been carrying out continuous educational innovation, insisting on student-centered, in class and out of the class combination, science and humanities combination, teaching and research combination, and gradually forming a unique innovative talent training mode. In 2012 and 2015, The National Experimental Teaching Demonstration Center selected by the Ministry of education of the people's Republic of China provided good experimental conditions for the cultivation of graduate students of various specialties. China's Ministry of education and the Ministry of Finance jointly issued the "opinions on the implementation of the innovation ability improvement plan of colleges and universities", which promotes the transformation of college education concepts, enhances college students' awareness and ability of innovation and entrepreneurship, and lays a solid foundation for the in-depth development of innovation education in colleges and universities. Innovation and entrepreneurship education aims to cultivate students' innovation consciousness, innovation thinking, innovation spirit, entrepreneurship quality and entrepreneurship skills. Its essence is to cultivate students' innovation spirit and practical ability. Guide students to transform their knowledge into ability, pay attention to the development of thinking development and psychological tolerance, so that college students can more adapt to the social development, and lay a solid foundation of thinking and professional skills.

The innovation and entrepreneurship ability of graduate students is a comprehensive and creative quality function, mainly composed of entrepreneurial knowledge structure, entrepreneurial consciousness, entrepreneurial quality and entrepreneurial psychological quality (Sun, Zhao, \& Shi, 2020). It is a comprehensive ability with business knowledge, practical ability and mentality building ( $\mathrm{Li}$ et al., 2020). Innovation and entrepreneurship ability embodies the indicators of the quality of entrepreneurship education. The improvement of ability is the starting point and destination of practical education. The cultivation of entrepreneurship ability is the core of entrepreneurship education, and the transfer of tacit knowledge is the key to the formation of entrepreneurship ability (Chai 2010).

The psychological quality of innovation and entrepreneurship education is reflected in people's independence, judgment, courage, tenacity, restraint, adaptability, cooperation, etc., which reflects the will and emotion of entrepreneurs. The development of College Students' entrepreneurial psychological capital can improve their entrepreneurial ability.

Some studies have found that the psychological quality of innovation and entrepreneurship education has a direct 
and indirect impact on individual innovation and entrepreneurship willingness. Niu (2015) concluded in the article that the impact of entrepreneurial psychology on entrepreneurial ability is not direct, but realized through the intermediary variable of entrepreneurial opportunity. The higher the entrepreneurial psychological capital of college students, the stronger their entrepreneurial intention, which shows that the students with positive psychological qualities such as optimism and courage are more inclined to start their businesses(Sun, \& Xu, 2020).

\section{Research Purpose}

Under the current situation of China's social and economic development, the transformation of economic structure and growth mode can be achieved through independent innovation. In the "mass entrepreneurship and mass innovation" theory, how to cultivate graduate students' innovation awareness and entrepreneurial skills has become a topic of common concern in domestic universities. In recent years, many colleges and universities in China have invested heavily in innovation and entrepreneurship education, carried out a series of teaching reforms, and achieved some results, but still can not meet the needs of the society for innovation and entrepreneurship talents. Through consulting the previous literature, we know that the weakness of entrepreneurship and innovation lies in the imperfection of the university education system and the lack of cultural atmosphere. For this problem, we put forward the hypothesis of the relationship among the willingness, psychology and ability of innovation and entrepreneurship. We develop a scale and build a hypothesis model by collecting items through an open-ended questionnaire to get the relationship between the three.

\section{Literature Review}

\subsection{Innovation and entrepreneurship ability and willingness}

Through combing the relevant literature, we found that in the existing literature, the basic research is the entrepreneurial willingness, entrepreneurial ability and entrepreneurial education. It shows that these three points are the most important factors in innovation and entrepreneurship and influence each other. At the end of the last century, Krueger (1993) first put forward a definition that entrepreneurial consciousness is the core of the entrepreneurial process. In this paper, Prodan, \& Drnovsek (2010) pointed out that the academic literature on entrepreneurship intention is almost blank. This makes the "entrepreneurial will" of the academic community begin to develop. Later, Obschonka, Silbereisen, \& Schmitt-Rodermund, (2010) explored the entrepreneurial intention and entrepreneurial ability and concluded that entrepreneurial intention is formed in the early stage of life through the development of entrepreneurial ability (such as leadership, adolescent research activities). Amanda et al., (2017) did the same research but defined that under adverse conditions, even under adverse conditions, if an individual can grow from adversity and believe in his entrepreneurial ability (entrepreneurial self-efficacy), he will also have entrepreneurial intention. As Liu, Lu, \& Li, (2020) have concluded, students majoring in special subjects are more confident in their entrepreneurial ability, so they are generally willing to innovate and start businesses. Some researches believe that there is a certain gap between the quality of graduate education and social needs, and the ability of graduates is difficult to meet the needs of innovation and entrepreneurship, so it is urgent to change the training mode of college students. Based on the investigation and analysis of the "student-centered" university education system in foreign countries, the author applies the teaching theory of constructivism in the research and believes that the construction of a learning situation suitable for the independent learning and scientific research of Liberal Arts Postgraduates can cultivate the innovative consciousness of postgraduates. According to the questionnaire survey and data analysis, four factors that affect the learning status of liberal arts students are experimental conditions, autonomous learning conditions, team cooperation and teacher guidance ( $\mathrm{Hu}, \& \mathrm{Zhang}$, 2015). Zhang $\mathrm{Mu}$ and others pointed out the necessity of the construction of the Chinese experimental teaching platform. Because of the quality and ability education of liberal arts students, combined with the current situation and characteristics of talent cultivation in tourism management (Zhao, Lai, \& Zhang, 2014).

Based on the previous discussion, the following assumptions are made:

Hypothesis 1: there is a positive relationship between graduate innovation and entrepreneurship ability and innovation and entrepreneurship intention.

\section{2 intermediary effect of psychological quality of innovation and Entrepreneurship Education}

Innovation and entrepreneurship education in Colleges and universities is a kind of education form that China vigorously advocates at present. It can not only relieve the employment pressure but also cultivate new talents with innovative thinking and ability. Pei, Wang, \& Zhou, (2019) used the MOA model to analyze the relationship between entrepreneurship education and ability, concluded that innovation and entrepreneurship education plays the most important role in improving the innovation and entrepreneurship ability of college students. Sun (2016) established the E-PCI-S psychological capital intervention model for the demonstration of this relationship, and concluded that the cultivation and improvement of College Students' entrepreneurial ability depend on the level of their educational psychological capital. Gilsing, Van Burg, \& Romme, (2010) also stressed the importance of an entrepreneurial atmosphere in universities. Therefore, it can be said that the educational psychology of college 
students affects the level of innovation and entrepreneurship ability, and it is also the key factor affecting the willingness of innovation and entrepreneurship.

Rauch \& Rijsdijk (2013) according to the sampling survey, from the perspective of education, college students have greater entrepreneurial potential and possibility. Gurel, Altinay, \& Daniele, (2010) believe that education plays a key role in fostering students' willingness to start a business. Strengthening the education of innovation and entrepreneurship can improve the students' willingness to start a business and help them transform their awareness of entrepreneurship into entrepreneurial behavior (Altinay, Madanoglu, Daniele, \& Lashley, 2012). Hayton, George, \& Zahra, (2002); Morrison, \& Alison, (2000) also confirmed that education can improve students' entrepreneurial ability.

Based on the previous discussion, the following assumptions are made:

Hypothesis 2A: there is a positive relationship between the ability of innovation and entrepreneurship and the psychological quality of innovation and entrepreneurship education.

Hypothesis 2B: there is a positive relationship between the psychological quality of innovation and entrepreneurship education and the willingness of innovation and entrepreneurship.

Hypothesis 2C: the psychological quality of graduate students' innovation and entrepreneurship education plays an intermediary role between graduate students' innovation and entrepreneurship ability and innovation and entrepreneurship willingness.

\subsection{Proposed model}

Based on the previous discussion, a conceptual model is developed, as shown in Figure 1.

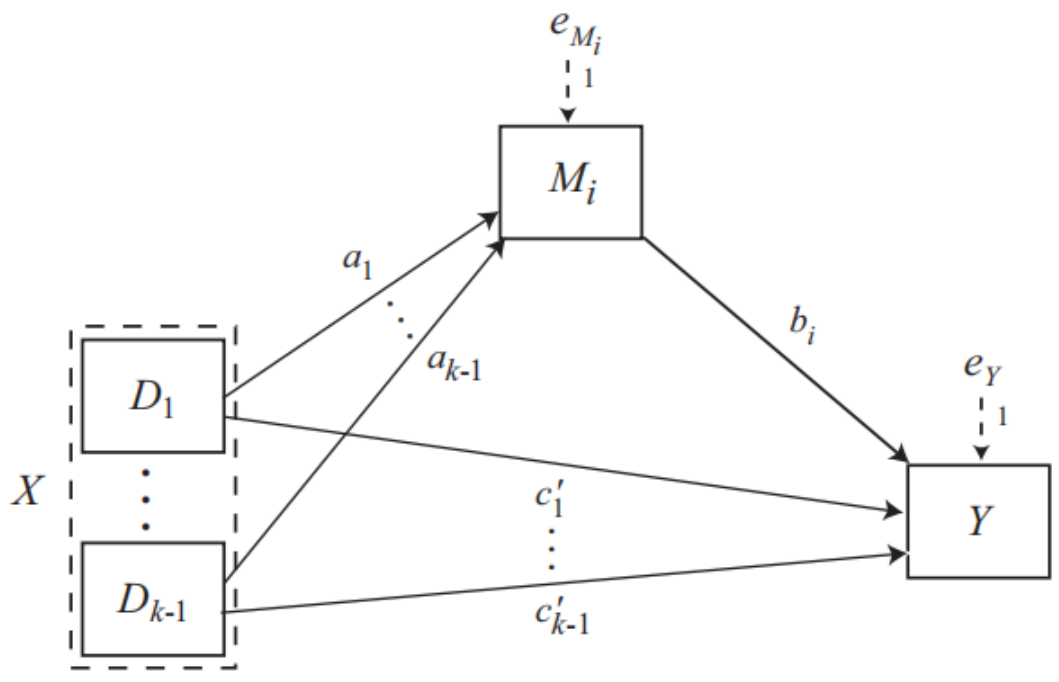

Note: Sources from model templates for process for SPSS and SAS, Andrew F. Hayes and the Guilford Press. X stands for innovation and entrepreneurship ability, Y stands for innovation and entrepreneurship willingness, Mi stands for innovation and entrepreneurship education psychological quality

Figure 1: Conceptual model

\section{Research object and method}

\subsection{Research object}

In December 2019, 300 graduate students were randomly selected from Shenzhen as the research objects. The questionnaire was used to collect basic personal information, psychological quality of entrepreneurship education, knowledge, ability, consciousness and willingness of innovation and entrepreneurship. 281 valid questionnaires were collected.

\subsection{Research method}

In this study, a literature review and questionnaire survey were used to collect data. Based on the study, this paper measures the ability, psychological quality and willingness of innovation and entrepreneurship. In the part of the questionnaire, combined with the actual research questions, the preliminary questionnaire survey is designed, small-scale data collection, and spss21.0 software is used to test the validity of the questionnaire.

4.2.1 Measurement of innovation and entrepreneurship ability ( AB)

It is composed of three items: "I am innovative, I can lead and guide team members and I have successfully planned many activities during my university or graduate period". With a 5-point score, the higher the score is, the higher the degree of entrepreneurial ability is. The internal consistency coefficient is 0.759 . This scale has been revised 
by domestic scholars and proved to have good reliability and validity.

4.2.2 Measurement of innovation and entrepreneurship willingness (BI)

There are three items in it, and the higher the score is, the stronger the willingness of innovation and entrepreneurship is. The internal consistency coefficient of the scale is 0.872 .

4.2.3 The measurement of psychological quality of innovation and Entrepreneurship Education(EP)

It is composed of three items, and the higher the score is, the stronger the psychological endurance is. The internal consistency coefficient is 0.814 .

\subsection{Statistical processing}

The data were analyzed by SPSS. Firstly, the demographic characteristics of the interviewees were analyzed. Then Cronbach's alpha is used to check the internal consistency of each construct, and the results show that the reliability is at an acceptable level. Finally, the score information of each construct is counted.

To test the main effect of the model, a series of multiple regression analyses were carried out. The process was used to test the mediating effect and moderating effect. The process is a plug-in specially used to analyze the intermediary effect test. In addition to the results of conventional regression analysis, it also provides the estimates of direct effect and indirect effect as well as the results of a bootstrap confidence interval and Sobel test. The process can also deal with multiple mediations, multiple mediations, mediations with mediations, mediations with mediations and other complex models. The process provides more than 70 models. In the process of analysis, you need to select the corresponding model and set the corresponding independent variable, dependent variable, intermediary or adjustment variable. Specifically, model 4 is selected in this study.

\section{Results}

5.1. Demographic profile

Table 1 descriptive statistics of demographic characteristics are divided into four categories, $31 \%$ for men and $69 \%$ for women, $35.6 \%$ for postgraduates, $31 \%$ for postgraduates, $33.5 \%$ for postgraduates, 87 for postgraduates, 94 for postgraduates and above, 115 for students from Guangdong Province, $40.9 \%$ for students from other provinces, and $59.1 \%$ for students from other provinces. 79 for students whose parents were or are entrepreneurs, $28.1 \%$ for students who have never been entrepreneurs 202 students accounted for $71.9 \%$.

Table 1: descriptive statistics of demographic characteristics

\begin{tabular}{llrr}
\hline Basic Feature & Category & $\mathrm{n}$ & $\%$ \\
\hline Gender & Male & 87 & 31.0 \\
& Female & 194 & 69.0 \\
Grade & First-year graduated school student & 100 & 35.6 \\
& Second-year graduated school student & 87 & 31.0 \\
Place of origin & Third-year graduated school student and above & 94 & 33.5 \\
& Guangdong Province & 115 & 40.9 \\
Have parents ever started a business or are & Non-Guangdong Province & 166 & 59.1 \\
they now starting a business & Yes & 79 & 28.1 \\
& No & 202 & 71.9 \\
\hline
\end{tabular}

Note: Respondents profile $(\mathrm{N}=314)$

Table 2 lists the mean, standard deviation, item-total correlation, and Cronbach's alpha values for each construct. As shown in Table 2, the Cronbach's Alpha coefficient is between 0.872 and 0.759 , and all constructs exceed the threshold value of 0.75 , indicating that the internal consistency between each scale is acceptable. The average of the three variables of innovation and entrepreneurship ability, education psychological quality and innovation and entrepreneurship willingness of postgraduates are all greater than 3.0, which indicates that the work of innovation and entrepreneurship education of postgraduates is well implemented. 
Table 2 reliability analysis results of each item in the scale

\begin{tabular}{|c|c|c|c|c|}
\hline & Mean & $\begin{array}{l}\text { Standard } \\
\text { deviation }\end{array}$ & CITC & $\begin{array}{l}\text { Cronbach's } \\
\text { Alpha }\end{array}$ \\
\hline Innovation and Entrepreneurship ( $\mathrm{AB})$ & 3.3440 & .71954 & & .759 \\
\hline I am innovative & 3.23 & .853 & $.742^{* *}$ & \\
\hline I can lead and coach team members & 3.33 & .882 & $.780^{* *}$ & \\
\hline $\begin{array}{l}\text { I've successfully planned many activities during my college } \\
\text { or postgraduate years }\end{array}$ & 3.47 & 1.052 & $.795^{* *}$ & \\
\hline $\begin{array}{l}\text { Psychological quality of innovation and Entrepreneurship } \\
\text { Education (EP) }\end{array}$ & 3.3808 & .74650 & & .814 \\
\hline $\begin{array}{l}\text { I can bear the uncertainty of innovation and } \\
\text { Entrepreneurship }\end{array}$ & 3.37 & .881 & $.838^{* *}$ & \\
\hline $\begin{array}{l}\text { I can overcome all kinds of difficulties on the road of } \\
\text { innovation and Entrepreneurship }\end{array}$ & 3.37 & .815 & $.873^{* *}$ & \\
\hline I have an adventurous spirit & 3.40 & .925 & $.854^{* *}$ & \\
\hline The willingness of innovation and Entrepreneurship (BI) & 3.1910 & .90518 & & .872 \\
\hline $\begin{array}{l}\text { If I have the chance and can make a decision freely, I will } \\
\text { choose to start a business }\end{array}$ & 3.47 & .960 & $.881^{* *}$ & \\
\hline I'd rather start a business than have a stable job & 3.16 & 1.037 & $.914^{* *}$ & \\
\hline $\begin{array}{l}\text { I think it's very possible for me to start a business in the } \\
\text { next five years }\end{array}$ & 2.94 & 1.044 & $.883^{* *}$ & \\
\hline
\end{tabular}

Note: $* *$ indicates that the correlation is significant at level 0.01

The three variable parts all adopt the 5-level scale, 1 means "very disagree", 2 means "comparative disagree", 3 means "uncertain", 4 means "comparative agree", 5 means "very agree". The average value of the first part is 3.34 , the first item is 3.23 , the second item is 3.33 , and the third item is 3.47 , indicating that graduate students are generally innovative and have leadership and planning ability. In the second part, the average value of the quality of innovation and Entrepreneurship Education (EP) is 3.38, the average value of the first item is 3.37, the average value of the second item is 3.37 , and the average value of the third item is 3.40 , indicating that the psychological endurance of postgraduates is generally high. In the third part, the mean value of innovation and entrepreneurship intention (BI) is 3.191, the mean value of the first item is 3.47 , the mean value of the second item is 3.16 , and the mean value of the third item is 2.94, indicating that graduate students are more inclined to start their businesses when they can choose their careers freely, but the possibility of starting their businesses in the next five years is low.

The fitting indexes of the confirmatory factor analysis model of the questionnaire were better, X2 / DF = 1.086, $\mathrm{RMSEA}=0.018, \mathrm{GFI}=0.984, \mathrm{AGFI}=0.963, \mathrm{NFI}=0.983, \mathrm{IFI}=0.999, \mathrm{TLI}=0.997, \mathrm{CFI}=0.999$. At the same time, the standardized factor load of each item is more than 0.5 but less than 0.9 , indicating that the aggregation validity of the questionnaire is good.

\subsection{Model and hypothesis test}

5.2.1 Main effect test

Using the method of regression analysis, whether the innovation and entrepreneurship ability of graduate students affects their innovation and entrepreneurship willingness. As shown in Table 3, after controlling the research innovation and entrepreneurship ability, the results of innovation and entrepreneurship intention are significant. The results show that there is a significant positive correlation between graduate students' innovation and entrepreneurship ability and innovation and entrepreneurship willingness $(\mathrm{b}=0.1551, \mathrm{P}<0.05)$, and there is a significant positive correlation between graduate students' innovation and entrepreneurship ability and innovation and entrepreneurship education psychological quality $(\mathrm{b}=0.5892, \mathrm{P}<0.001)$. These results provide support for $\mathrm{H} 1$ and $\mathrm{H} 2 \mathrm{~A}$.

Table 3 Regression analysis of the main effec

\begin{tabular}{|c|c|c|c|c|c|c|c|c|}
\hline $\begin{array}{l}\text { Dependent } \\
\text { Variable }\end{array}$ & $\begin{array}{l}\text { Independent } \\
\text { Variable }\end{array}$ & B & S.E. & $\mathrm{t}$ & $\mathrm{P}$ & $\begin{array}{l}95 \% \\
\text { interval } \\
\text { LLCI }\end{array}$ & Confidence & Hypothesis \\
\hline \multirow[t]{2}{*}{ BI } & $\mathrm{AB}$ & .1551 & .1551 & .0662 & 2.3426 & .0199 & .0248 & .2854 \\
\hline & $\mathrm{R}^{2}$ & .4784 & .4784 & $\mathrm{~F}=12$ & $.5097, \mathrm{p}$ & 0.001 & & \\
\hline \multirow[t]{2}{*}{ EP } & $\mathrm{AB}$ & .5892 & .5892 & .0511 & 11.5248 & .0000 & .4886 & .6898 \\
\hline & $\mathrm{R}^{2}$ & .3225 & .3225 & $F=132$ & $8212, \mathrm{p}$ & 0.001 & & \\
\hline
\end{tabular}

5.2.2 Intermediary effect test

It is assumed that the psychological quality of innovation and entrepreneurship education plays an intermediary 
role between graduate students' innovation and entrepreneurship ability and willingness. According to the mediation effect analysis program, refer to Hayes's model 4 and the bootstrap method for mediation analysis, and the results are shown in Table 4 . When the sample size is 5000 and the $95 \%$ confidence interval, the result of the intermediary test does not contain $0(\mathrm{LLCI}=0.3394, \mathrm{ULCI}=0.5550)$, indicating that the intermediary effect of the psychological quality of innovation and entrepreneurship education is significant, and the size of the intermediary effect is 0.4388 . Besides, after controlling the psychological quality of innovation and entrepreneurship education, the influence of independent event attachment on dependent variable behavioral intention is still significant, and the interval ( $\mathrm{LLCI}=0.4208$, ULCI $=0.5990$ ) does not contain 0 . Therefore, the psychological quality of innovation and entrepreneurship education plays a part in an intermediary role in the influence of graduate students' innovation and entrepreneurship ability and willingness. The results provide support for H2B.

Table 4 Regression coefficient of the intermediary model

\begin{tabular}{lllllll}
\hline Model & Effect & S.E. & \multicolumn{2}{l}{ 95\% Confidence interval } & Hypothesis & Model \\
& & & Boot Lower & Boot Upper & & \\
\hline $\mathrm{AB} \rightarrow \mathrm{EP} \rightarrow \mathrm{BI}$ & .4388 & .0542 & .3394 & .5550 & $\mathrm{H} 2 \mathrm{~b}(\mathrm{~S})$ & $\mathrm{AB} \rightarrow \mathrm{EP} \rightarrow \mathrm{BI}$ \\
\hline
\end{tabular}

\section{Discussion and conclusion}

Through a questionnaire survey of innovation and Entrepreneurship of graduate students in Colleges and universities, the paper concludes that the willingness, ability and psychological quality of innovation and entrepreneurship education interact with each other. Graduate students in Colleges and universities have a good foundation and enthusiasm for innovation and entrepreneurship, and their awareness of innovation and entrepreneurship is at a medium and high level. However, some of the students are uncertain about their ability to innovation and entrepreneurship. Colleges and universities need to strengthen the education and training of innovation and entrepreneurship. Another part of students believe in their ability of innovation and entrepreneurship, so they are willing to do so. This is consistent with the conclusion of (Liu, Lu, \& Li, 2020). Most graduate students have mature psychological quality, which is closely related to innovation and entrepreneurship education. The answer to the open question shows that under the strong advocacy of the state, innovation and entrepreneurship have been deeply into the lives of university graduate students, which has a positive impact on innovation and entrepreneurship.

\section{Countermeasures and suggestions}

Nowadays, the innovative consciousness and entrepreneurial skills of graduate students have become the focus of higher education. Innovation awareness usually requires a collection of knowledge of various disciplines, which can make college students comprehensively think about problems and put forward solutions. However, students are not willing to spend too long time cycle to fully receive education and then obtain the spirit of innovation and entrepreneurship. Therefore, colleges and universities can carry out open and innovative experimental projects in each teaching cycle, such as one semester, one academic year, so that students can get inspiration from them, which is a thought worth trying. Classroom teaching usually imparts systematic knowledge and skills, which can guide graduate students to master specialized and regular knowledge systems. However, the innovation and entrepreneurship awareness can not be cultivated by following the rules and regulations. It can integrate the open learning environment into the traditional professional teaching system, and create an educational activity suitable for the graduate students in Colleges and universities to cultivate innovation and entrepreneurship awareness. And using the project research of fragmentation, we can enlighten the innovation and Entrepreneurship of university graduate students in a short time.

Classroom teaching carries a systematic task of knowledge transfer, and scientific research has always been a fragmented application of knowledge integration. The cooperation between them is the key link to inspire the innovation and entrepreneurship consciousness of university graduate students.

\section{References}

Altinay, L., Madanoglu, M., Daniele, R., \& Lashley, C. (2012). The influence of family tradition and psychological traits on entrepreneurial intention. International Journal of hospitality management, 31 (2), 489-499.

Bullough, A., Renko, M., \& Myatt, T. (2014). Danger zone entrepreneurs: the importance of resilience and selfefficacy for entrepreneurial intentions. Entrepreneurship Theory and Practice, 38 (3), 473-499.

Chai, X. D. (2010). University Entrepreneurship Education from the Perspective of Tacit Knowledge. Research in Higher Education of Engineering , (01), 75-80.

Gilsing, V. A., Van Burg, E., \& Romme, A. G. L. (2010). Policy principles for the creation and success of corporate and academic spin-offs. Technovation, 30 (1), 12-23.

Gurel, E., Altinay, L., \& Daniele, R. (2010). Tourism students' entrepreneurial intentions. Annals of Tourism Research, 37 (3), 646-669.

Hayton, J. C., George, G., \& Zahra, S. A. (2002). National culture and entrepreneurship: A review of behavioral 
research. Entrepreneurship theory and practice, 26 (4), 33-52.

Hu, J. \& Zhang, M. (2015). Research on the Construction of Liberal Arts Graduate Student Learning SituationA Case Study of the Tourism Management Major in Guangdong Province. Higher Education Studies , 5(2), $1-9$.

Krueger, N. (1993). The impact of prior entrepreneurial exposure on perceptions of new venture feasibility and desirability. Entrepreneurship theory and practice, 18 (1), 5-21.

Li, F. G., Tang, X. Y., Li, Y. H., Xiao, S., \& Dong, L. (2020).On the method and effect of training college students' innovation and entrepreneurship ability in business-war competition: Based on the practice of building a business competition platform between the Marketing Department of Chongqing Three Gorges University and "Liangcaiduo Company". Journal of Innovation and Enterprise Education , 11 (02), 83-86.

Liu, Q., Lu, L. N., \& Li, J. (2020). Research on the Present Situation and Countermeasures of Undergraduates' Innovation and Entrepreneurial Intention and Ability - A Case Study of Resource Exploration Engineering in the Institute of Disaster Prevention. Education Teaching Forum , (05), 130-131.

Morrison, \& Alison. (2000). Entrepreneurship: what triggers it?. International Journal of Entrepreneurial Behavior \& Research , 6(2), 59-71.

Niu, H. (2015). A Research of the relationship between College students' entrepreneurial psychological capital, entrepreneurial opportunity ability and entrepreneurial performance. Chongqing Normal University Master Degree Thesis.

Obschonka, M., Silbereisen, R. K., \& Schmitt-Rodermund, E. (2010). Entrepreneurial intention as developmental outcome. Journal of Vocational Behavior , 77 (1), 63-72.

Pei, Y. N., Wang. C. W., \& Zhou, J. (2019). Research on Influencing Factors of College Students' Innovation and Entrepreneurship Education under Project Driven--Empirical analysis based on MOA model. Higher Education Exploration , (07), 108-116.

Prodan, I., \& Drnovsek, M. (2010). Conceptualizing academic-entrepreneurial intentions: An empirical test. Technovation , 30 (5-6), 332-347.

Rauch, A., \& Rijsdijk, S. A. (2013). The effects of general and specific human capital on long-term growth and failure of newly founded businesses. Entrepreneurship Theory and Practice , 37 (4), 923-941.

Sun, D. P., Zhao, W, J., \& Shi, J. (2020). Improvement of college students' Entrepreneurial Ability under innovation and Entrepreneurship education. Chinese \& Foreign Entrepreneurs , (15), 195.

Sun, Y. H., \& Xu. Q. Y. (2020). The Relationship Between Work Values and Entrepreneurial Intention of College Students:the Regulating Role of Entrepreneurial Psychological Capital. Youth and Adolescent Studies , (02), 27-31.

Sun, W. (2016). Cultivation of College Students' Entrepreneurial Decision-making Ability under the background of supply-side reform -- Analysis of psychological capital intervention model based on E-PCI-S. Journal of Innovation and Enterprise Education , 7 (03), 17-22.

Zhao, L., Lai, J. Y., \& Zhang, M. (2014), A Design and Construction of Experimental Teaching Platform on Quality and Competence Training Targeted at Students of Liberal Arts. Journal of Education and Practice. 5(7), 142-149. 